\title{
SOCIO-PSYCHOLOGICAL ASPECTS OF DEVELOPMENT OF PERSONALITY DEMOCRACIES IN MODERN UKRAINE
}

\section{Vynohradova V. Ye.}

\section{INTRODUCTION}

The modern life is characterized by a rapid rate of development. The progress of all areas of human activity depends on people who perceive the world creatively and can achieve high results in a sphere of action. The importance of the problem of the creative development of the personality of a young person is perceived to the extent it is innovative in all state documents about education, speeches of specialists who are responsible for the development of the education system.

This is due to according to analysts up to $50 \%$ of workplaces in classical areas will disappear in the nearest future. However, in creative industries workplaces will be created sufficiently rapid pate.

The creative economy influences the educational system, youth, investment climate and investment attractiveness of goods, regions, and a whole country. The main values are the staff, its creative capabilities, and the non-standard approach to the case at the stage of transition from a market economy to a creative one that is characterized by the rapid growth of technology.

Creative industries are a set of views, ideas, trends, and trends of modern economic development which are characterized by an organic combination and the use of knowledge, information, and creativity.

Consequently, it is necessary in the modern world to develop not only creativity as a quality of an individual but also creative industry in general. That is, nowadays creativity has become a key vector for a society based on knowledge and economy. It contributes to all areas of public life such as politics, business, culture, art, and also is an instrument in the stable development of a country. So, the development of creative industries is extremely important.

It should be noted that studying the development of creative abilities has a long term way. Ukrainian and foreign scientists facilitate new development in studying this problem in the 21 st century. The process of 
formation of creative abilities worries scientists of all time and continents. Nowadays, scientists study not only the development of general and special abilities but also trying to identify the main approaches for developing creative thinking in children and adults. They study the creation of a model that can develop creativity clearly and step by step. The importance of the study is the necessity of theoretical synthesis and specification of the methodological foundations of the problem of the development of creative abilities (general psychology). The implementation of historical and psychological analysis of its scientific and conceptual, socio-value and personal factors (history of psychology), and building of an optimal educational and pedagogic environment in which there is an effective development of abilities and giftedness (age and pedagogical psychology) are the importance of the study as well. Creating conditions for early detection and development of creative abilities is one of the priorities of the modernization of national education which often remains focused on the so-called average student practically.

Consequently, the developed theories and concepts of the development of creative abilities in Ukrainian and foreign psychological science need to systematize the factors of its development and the establishment of such uniqueness which will provide a holistic understanding of the problem. This involves studying the main points of the way of life and the main factors that influence the development of the creative abilities of the individual. Scientists V.G. Panok and G.V. Rud have determined that the set of social, biological, and environmental factors that influence the person throughout his life are attributed to the life circumstances. An individually unique "personal history" and the individuality of each person should be determined ${ }^{1}$.

The scientists grounded the necessity to direct the attention of educational institutions to the formation of creative abilities during the educational process. However, if the factors of personality are taken into account, then this process is more effective in the significant opportunities of the socio-cultural environment. However, there are many difficulties in solving this problem.

Accordingly, we consider the problems of the development of the creative abilities of the individual which are connected with the sociopsychological factors that influence the development of the individual. In

\footnotetext{
${ }^{1}$ Панок В.Г., Рудь Г.В. Психологія життєвого шляху особистості: Монографія. - К.: Ніка-Центр, 2006. $-280 \mathrm{c}$.
} 
our opinion, the problems of personality formation under the influence of such systems as family, developmental space, and educational institutions should be considered.

\section{The influence of socio-cultural conditions for personality change development}

It is well known that one of the most important factors influence the development of the individual is the environment to the extent it is developing or vice versa. Nowadays, the issue of the development of creative abilities and talents tend not only corporations but the state and even the world. For instance, the Martin Prosperity Institute (the University of Toronto) provides data annually on the creativity and creative nature of 139 countries in the world. According to the index of creativity, countries are estimated by three indicators of economic development - technology, talent, and tolerance. It should be noted that the rating is influenced by the share of investments in research, the number of researchers and patents per head, the quality of education, and others.

According to the ratings of recent years, Australia has been recognized as the most creative country, in the second place - the USA, in the third - New Zealand. The top ten countries are Canada, Denmark, Finland, Sweden, Iceland, Singapore, and the Netherlands. These countries are considered to be very successful today. Ukraine was ranked 45th out of 139 in this ranking which is a rather high indicator. At the same time, Ukraine has quite good positions compared to many other countries by the level of talents that could contribute to the higher positions of Ukraine in this ranking. However, our country is still significantly losing positions in terms of tolerance of society. It should be noted that Britain introduced the creativity of employees into the factor of GDP formation in the country.

Professor John Howkins of Economics proposes to consider creativity as the main general capital. He identified three principles for the formation of a creative environment ${ }^{2}$.

1. This versatility of creativity (all people have creative abilities; they are given to each child).

2. Freedom (the actual attitude to any idea - to accept or reject).

3. Formation of markets and connections for the successful implementation of ideas.

\footnotetext{
${ }^{2}$ Хокинс Д. Креативная экономика. Как превратить идеи в деньги. - М.: Классика - XXI, 2011. - 172 с.
} 
At the same time, the main task is to transform freedom into effective economic activity.

The Analytical Center CEDOS has developed an index of the cultural and creative potential of cities. More than one hundred indicators were collected for the largest cities of Ukraine such as Dnipro, Kyiv, Lviv, Odesa, and Kharkiv. The research has determined the creative potential of the city, that is, how much the city environment can affect the development of personality creativity. The components of the city environment included the number of libraries, museums, theaters, cinemas, etc. Indicators showed how the significant opportunities of the city for the development of talent were. However, there are no such studies in all cities of Ukraine today. If we take these indicators, the environment contributes to the development of the creativity of the individual to a certain extent in large cities, taking into account the available opportunities. However, the environment is not adapted to develop the creativity of the younger generation in small towns and rural areas.

Professor Michael How of the University of Exeter believes that creative achievements are dependent heavily on general behavioral factors and environmental characteristics. He agrees that everyone is endowed with a gift of creativity but only a few people have the necessary qualities to develop it to the full. It is needed a long mood, an exact sense of purpose, a strong motivation for success, the ability to focus on specific tasks, and often understanding and support for homework.

Creative Director of Endemol Entertainment UK, one of the major European television program groups Peter Bazalgette calls six characteristics of creative people. The first characteristic is openness: "This means that you allow your consciousness to wander almost like a dream." The second quality is the independence of consciousness: "Creative people violate the rules but not establish them." The third characteristic - they are not afraid of changes. The fourth characteristic is "a test of a clean sheet ... creative people feel the challenge of space and try to put something on it." The fifth characteristic is a well-developed sense of humor. Then lastly, he states that creative people are ambitious and ready to compete ${ }^{3}$.

It should be noted that gifted people deviate from the norm not because they have some sort of rare abilities but they do not have a block or a filter that is applied on the talent that inherent with all. Researchers

\footnotetext{
${ }^{3}$ Хокинс Д. Креативная экономика. Как превратить идеи в деньги. - М.: Классика - XXI, 2011. - 172 с.
} 
concluded that the psychological nature of creativity is general to all. The rareness is our ability or a natural psychological opportunity to use it. There is the general innate ability to engage in creativity but not to the production of creative products. Anyone can dream and have an idea. Far fewer people can create a creative product. It depends on the technical skills, physical resources, and possibly environmental factors.

However, those children who find themselves in unfavorable conditions of the development, unfortunately, have rather insignificant opportunities for the realization of their potential. This is confirmed by numerous scientific studies of the influence of the environment on the development of creative abilities. For instance, according to the results of cross-cultural research of $\mathrm{P}$. Torrance, the following provisions are defined:

- Peculiarities of the environment affect the type of creativity and the process of its formation;

- The development of creativity is not genetically determined but depends on the culture in which the child develops;

- The development of creative abilities does not involve pausing in its process;

- Reducing the level of creativity can be explained by the extent to which new demands and stressful situations are encountered by the child;

- Creativity can be developed at any age through special education ${ }^{4}$.

Gippenreiter Y. having analyzed the conditions of education and heredity concluded that the factors of the medium are quite significant in comparison with the factor of heredity. They can compensate sometimes completely or conversely, neutralize the actions of the latter ${ }^{5}$ V. Druzhinin's confirms the previous statement. He believes that creativity is actualized only under significant opportunities for environmental. It is necessary to create the following conditions for the formation of creativity. Firstly, this is the presence of a positive sample of creative behavior. Secondly, this is the absence of a sample of regulated behavior. Third, this is the creation of conditions for the pursuit of creative behavior. Finally, this is a social reinforcement of creative behavior ${ }^{6}$. Salvador Dali advised:

\footnotetext{
${ }^{4}$ Torrance E.P. Rewarding Creative Behaviour. Experiments in classroom creativity / E.P. Torrance. Prentice Hall, 1965. - P. 353.

5 Гиппенрейтер Ю.Б. Общаться с ребенком. Как? / Ю.Б. Гиппенрейтер. - М. : ЧеРо, Сфера, 2003. $118 \mathrm{c}$.

6 Дружинин В.Н. Психология : учебник для гуманитарных вузов / В. Н. Дружинин. - [2-е изд.].СПб. : Изд. дом ПИТЕР, 2007. - 656 с.
} 
"It is necessary to create confusion systematically, it frees creativity." Creativity is complexity.

The conditions that are necessary for the demonstration of creativity are listed in a provision developed in the concept of humanistic psychology. It states that it is necessary to create conditions for identifying the child's internal capabilities. However, it is not necessary to speed up the creative development of a child. P. Torrance has identified the following conditions that can contribute to the formation and development of children's creativity. These are the orientation of a child to creative decisions; removing obstacles to the child's initiative; encouragement of creativity at home and in preschool; possibility to act with thoughts and objects; education of the child's knowledge of the value of the creative features of his/her personality; attention to all the properties of the environment. K. Rodgers distinguished internal and external conditions that contribute to the development of the creative potential of the individual. To the internal conditions he attributed the child's openness to experience; an internal evaluation of his/her creativity ("whether I am satisfied, but not satisfied with me"), and the ability to play with images and concepts. However, to obtain internal conditions, it is necessary to create external conditions. The external conditions include providing psychological safety (respect for a child as a person, the absence of external assessments), and psychological freedom (freedom in expressing their feelings and deeds).

Thus, the creation of an environment in which a child can be independent, exercise freedom of choice, respect for a child and the absence of excessive demandingness to him/her, and contributes to the formation of her creative abilities.

\section{Problems of development of personalities in the modern Ukrainian family}

A family serves as a model and an indicator of its problems in any period of development of society. The average family reflects the same economic, moral, spiritual, and value controversies that are currently present in the state. Therefore, the current socio-economic condition of the development of Ukrainian society highlights problems on the example of the life of most modern Ukrainian families. 
The great importance of the family in the upbringing of children is due to the peculiarities of its influence - continuity, consistency, and the fact that it educates not only through direct educational effects but also at the moral and sensory level which ensures high efficiency of the results and their long-term sustainability.

Tiutiunnyk V.I. notes that the need and ability to work in creative is formed for five years. In his opinion, the main factor contributing to the development of creative abilities is the impact of the relationship between the child and adults, and the attitude and position of adults towards a child.

It should be noted that there are the most advantageous, optimal terms in the development and development of individual abilities. There is an interesting observation of G. Lehmann Canadian scientist who has been working on this problem for about 20 years. In his opinion, the poets' age is determined between 26 and 30 years, doctors - 33-34, artists - 30-35, and writers $-40-44$ years $^{7}$. Giftedness can lead to the early development of abilities. Thus, the musical abilities of W.A. Mozart, J. Haydn, and M.A. Rimsky-Korsakov revealed in 4 years old; creative abilities of I.Y. Repin - at 4-5 years, and S. Raphael - at 8 years; A. Pushkin began to write the first verses in 9 years.

Some scholars identify the following factors that influence the formation and development of children's creative abilities:

- The harmony of relationships in a family between parents, between parents and children as well;

- Creativity as an indicator of personality as an example of imitation and the subject of identification;

- The commonality of intellectual interests of family members;

- Parents' expectations concerning the child: expectations of "achievements or independence" 8 .

However, there is an opposite position regarding the influence of harmonious relationships in a family on the development of creative abilities. These are a strict discipline, the same requirements for all children, and harmonious relationships between family members lead to the formation of certain social stereotypes and patterns of thinking making it impossible to develop children's creativity. The scientific research confirms the connection between non-harmonic emotional relationships in a family and the high creativity of children. Accordingly, it can be assumed

\footnotetext{
7 Леман К. Новий підліток до п’ятниці. / К. Леман. - [2-е вид.]. - К. : Брайт Букс , 2017. - 336 с., С. 49.

${ }^{8}$ Біла І.М. Психологія дитячої творчості. - К. : Фенікс, 2014. - 136 с., С. 61.
} 
that the most range of allowed behavioral (including emotional ones); less uniqueness of requirements and control contributes to the development of creativity. As a rule, a creative person is psychologically unstable and requires freedom. It is the requirement of parents of obedience that does not contribute to the development of independence and as a consequence, creativity.

If the parents pay attention to developing the abilities of a child and aim to develop his/her talent, this position is usually advantageous for the development of creativity. This process takes place under the influence of a favorable micro environment based on the general giftedness of a child, the formation of a system of motives, and personality traits. Thus, general giftedness is transformed into actual creativity (the synthesis of giftedness and a certain structure of personality). According to the researchers of creativity, the formation of these personality traits occurs in the period from three to five years.

According to D. Elkonin's research, children of preschool age develop approaches for the imitation of adult activities. Probably, during this period a child is as sensitive as possible to the development of creative abilities through imitation.

In the previous chapter, we have already highlighted the importance of a child's development environment. It is the family atmosphere that promotes the emergence of new thoughts and ideas, is the first necessary condition for the development of creative abilities.

In order to feel free in child's creative expressions, it requires the creation of an atmosphere in the first place, in which s/he will feel psychologically protected. The criticism of adults influences pretty negatively during this period. A friendly home atmosphere, permeated with spirituality, sympathy one-to-one family members, mutual understanding, a desire to be useful to their families, joint work, family holidays, folk customs, and rituals have an extremely profound influence on children and allow them to show their inclinations and develop creativity.

It should be noted that the formation of the individual requires longterm, systemic influence. Possibilities of the normal functioning of a family as a social institution are determined by its material security. The level of life and educational capacity of the family depends on the sociodemographic composition of the family such as the number of children, working and dependents, age of family members, their educational and 
professional level, etc. The most vulnerable are large families, single-parent families where one mother is raising children, and families with disabled children. Children in a family significantly reduce its financial capacity and average income per person. This level is 3 to 4 times lower in families with three or more children than in uniparous families which may be reflected in the conditions of the maintenance and upbringing of children.

The number of children in the parent's family affects the development of the creative abilities of each child. The interesting fact is that the greatest chances to show creativity, as a rule, have the eldest or the single son in a family. Fewer chances of showing creative abilities have children who identify themselves with their parents (a father).

In the information revolution, a large number of mothers and fathers are aware of the importance of the first years of child development. However, the information they receive is usually from the Internet and less often from books. This is not systematic, coherent, and purposeful for the development of the creative abilities of the individual. Hence, it should be noted that the main direction of society should be aimed at increasing the psychological and pedagogical literacy of the population.

Usually, a child comes to pre-school establishments in three years. Consider the realities of the present, a large number of children do not attend kindergarten because of the lack of places in kindergartens, their absence in many rural areas, and the family circumstances of parents. In most cases, children are deprived of a developing environment in which they can show their talents in a specific area. It should be noted that even if a child attends a pre-school, this does not guarantee him/her complete development. Consequently, an under three-years-old child and sometimes up to six grows and develops in a family circle. It is the parents who have to pay enough attention to personality development.

\section{Distinctions of the development of personal creative abilities in the educational system of Ukraine}

The impact of the educational system on personal formation and development is unquestionable. Today a great deal of attention is focused on the reform of secondary and higher education. The issue that comes on the foreground is not only gaining a certain amount of knowledge by children but the formation of an independent individual who is capable to use his/her creative potential. 
Creative abilities are considered as an integral property of personality and are defined as the high level of development of his/her abilities. An integral property of personality is studied in the context of the research on the development of skills and abilities, and individual traits of personality (N.S. Leites, K.K. Platonov, S.L. Rubinstein, B.M. Teplov), plus his/her stylistic aspects (O.V. Libin, V.S. Merlin), and the specific strategic activity (V.O. Molyako, T.M. Titarenko), including personality orientation (L.I. Bozhovich, A.M. Leontiev). The elaborated theories and concepts of the development of the creative abilities require the systematization of the factors of their maturity and equally the establishment of conceptual originality to provide a holistic understanding of the problem. It implies the study of historical links of conceptual tenets that presuppose further research perspectives.

In modern Ukraine, this issue is studied by such scholars as G.O. Ball, I.M. Bila, P.P. Gornostay, V.O. Molyako, O.L. Musika, L.P. Mishchykha, V.V. Rybalka, V.A. Romenets, S.O. Sysoev, etc. Among psychologists, however, there is a lack of consensus regarding the formation and development of creative abilities. A part of scholars hold that creative abilities and creativity are identical concepts that do not depend on the intelligence (J. Guilford, G. Gruber, Y.O. Ponomaryov, K. Tailor, P. Torrens); while others, on the contrary, find a correlation between a high level of intelligence and the creative abilities (G. Eysenck, D. Wexler, R. Sternberg). Also, some scientists argue that the motivations, individual psychological traits, emotional states along with other characteristics are the main factors for the disclosure of the creative abilities (D.B. Bogoyavlenskaya, A. Maslow, A. Olokh).

It is the well-known assumption that abilities are formed in the process of activities. Today the scholars in their researches, however, focus on the peculiarities of the psychological organization of the individual, namely, on the potential personal reserves because the creative attainment depends on them.

The analysis of the school system with general primary education demonstrates that it is mainly aimed at gaining the knowledge, skills, and abilities but not always accompanies by the development of the very creative abilities of the individual. It also should be noted that a child already starts schooling at age six or seven. And some sensational periods 
are passed over. As a result, the educational setting is no longer able to develop certain spheres of creative abilities.

Consider the impact of all parts of the learning environment on the development of personal creative abilities. In general, an important condition for organizing an inventive atmosphere is creating a sense of psychological security in children. It should be remembered that the critical remarks to the children and creating the feeling that their proposals are inappropriate lead to suppression of their creative abilities. In our opinion, it is important when the mentor treats the thoughts of the child without irony and with respect. Moreover, the educator should encourage the child to solve complex tasks to develop his/her motivation and persistence.

It is also necessary to note that the atmosphere and the physical setting exercise an important influence on the development of creative abilities. The children's room where preschool learning is performed should be designed following the chosen activities because the children must be able to move freely from one part of the room to the other without asking permission of a mentor. The group should be provided with various materials and equipment that are at the full disposal of the children. The mentor becomes the consultant and assistant to the children. While accomplishing the functions of general control over the activities in the group the tutor allows children to build the creative process by themselves. The well-known M. Montessori's system of the developmental environment is aimed at the comprehensive development of the child's personality and the formation of creative abilities. Unfortunately, it is poorly represented in Ukraine.

The next factor in the development of the child's creative potential, both in preschool and in school, is keeping the principles of personally oriented, developmental education, which directly ensue from the ideas of humanistic psychology (V.V. Davydov, L.B. Zankov, L.C. Vygotsky, D.B. Elkonin, I.S. Yakimanska, etc.). Developmental education is characterized by such an essential feature that creates a zone of immediate development. It also causes and facilitates or activates internal new psychic processes: the development of self-consciousness, feelings as a holistic process of personal development, because the values of life and moral norms only through feelings become personal values and norms of the developing individual, and are kept by him/her. It is also, suffices to say 
that the approach to the problem of developmental education is based on cultural-historical theory tenets of L.C. Vygotsky. The developmental education goal is apparent in the integrity and the utmost effectiveness of teaching, and the development of theoretical thinking (D.B. Elkonin, V.V. Davydov).

The goal includes such tasks as the formation of a learner, who is interested in self-transformation and capable of such changes, the comprehensive development, the development of cognitive needs, the formation of intellectually active personality, etc. In a person-oriented educational development, I.C. Yakimanskaya emphasizes the development of individual abilities of every child; maximum disclosing, initiation, usage, "culturing" of the individual (subjective) experience of the child; assisting the person rather in self-understanding, self-determination, and self-realization, than in the formation of predetermined characteristics ${ }^{9}$.

The person-oriented developmental education is characterized by the following presuppositions: the personality is manifested in an early childhood; from his/her birth a child is an entire human person, and he/she is a subject rather than an object in the pedagogical process; the personality is the goal of an educational system, but not a means for achieving other external goals.

A.M. Matyushkin sets forth the following principles of developmental education: problem, dialogue, and individualization. He considers that the conditions of the creative development are the problem-posing and dialogic, and individualized teaching. The disclosure of the creative potential involves activation and intensification of the developmental teaching of the children. It is rather important to teach how to think, and to find a solution to a problem than to give children ready-made answers. The problematic situation should be solved in a dialogue with the adult. The principle of individualization means that all kid's thoughts and statements, and all forms of their expression and demonstration are accepted ${ }^{10}$.

The development of personality following the principles of humanistic psychology is performed with the assistance of the following assumptions:

- To see in every child a unique person, to respect him/her, to understand, to accept, to believe in him/her ("All children are talented" this is the conviction of the teacher);

\footnotetext{
${ }^{9}$ Якиманська I. Особистісно орієнтована система навчання // Завуч. - 1999. - № 7. - С. 22.

${ }^{10}$ Матюшкин А.М. Проблемные ситуации в мышлении и обучении. - М., 1982.
} 
- To create the situation of success, overcoming, and achievement for the child;

- To rely on the positive traits of the personality;

- To exclude direct coercion, and also an emphasis on lagging and other disadvantages of the child;

- To understand the causes of child's ignorance and wrong behavior and correct them without degrading the dignity of the child's I-concept ("The child is good, but his/her deed is bad");

- To get excited by every child's idea, just as one can get excited by the baby's first steps:

a) To develop curiosity, the ability to raise questions,

b) To ensure independence in choosing and making decisions;

c) To comment positively all answers;

d) To use an error as an opportunity to look with new eyes at familiar things;

e) To be adapted maximally to all the statements and actions of children.

It should be noted that among the general pedagogical conditions of development of creative abilities of students in the process of learning the following are distinguished:

- Pedagogical stimulation of development of creative abilities based on the person-centered character of interaction between a teacher and pupils. The necessity to implement this condition is followed by modern social priorities. The person-centered interaction between the teacher and the student implies the choice of the characteristics of education and pedagogy as communication in which there are no sharp positions of the polarity of the student and the teacher. The process of education transforms into interaction. It contributes to the stimulation of activity, selfsufficiency, and the initiative of children; the combination of creative freedom and the direction of the students, emotionality, and expressiveness of communication with the expressions of respect and benevolence of participants in the pedagogical process.

- Application of psychological and pedagogical technologies that provide students with independent activity in the process of creative activity. The fulfillment of this condition must guarantee a positive motivation for the creative activity of junior pupils and provide an effective range of psychological and pedagogical incentives that will direct 
students' activity in the required direction. Such psychological and pedagogical technologies should take into account the peculiarities of pupils of different age groups, provide optimal conditions for students to express themselves, rely on material that is meaningful for students, involve their emotions in the process of creativity, encourage students in the process of creative activity to reflect their sensory experience in full, and provide the opportunity to create independently.

- System of educational work with pupils in the conditions of the creative and developing environment. In everyday life, knowledge is closely intertwined with each other, forming a unified system. Therefore, the student must see the object or phenomenon systemically in unity with the connections he enters. Maximum positive, favorable conditions for the development of children's creativity, including educational, for the upbringing of a creative person, creates a developing environment.

If study the development of the creative abilities of students, it should be noted that the demonstrations of creativity are quite controversial at this period. At this stage, the student solves mental tasks relatively easily, quickly, and efficiently. S/he can abstract freely from the concrete visual material and reasoning in a verbal way. Students are flexible, plasticity, ready for change and openness, and cooperation. The thinking of this age group is characterized by more flexible transitions in the interconnections of figurative, logical, and active components.

In parallel with the development of thinking, imagination and attention are developed. This is a positive factor in the manifestation of creativity $^{11}$. A student formulates a clearly expressed personal opinion and a self-chosen position. S/he has a huge creative potential that needs to be developed and which can not be given up. The activity of a person has a very significant significance for thinking as a higher mental process. Classroom activities are a prerequisite for developing students' skills and abilities to solve their problem tasks.

To formate creativity as a personal and not just behavioral, a specially organized environment is required. So-called "local" techniques for developing creativity (e.g. performing non-standard tasks) are useful. As a result of their use, students learn often only some new ways to perform a task and subsequently reproduce the assimilated actions (e.g. teams for participation in intellectual competitions are trained especially). In such

${ }^{11}$ Кривопишина О.А. Психологія творчості [Текст] / О.А. Кривопишина. - Суми: СумДУ, 2009. - 81 с. 
cases, creativity is showed in response to external actions in certain circumstances and not as a result of the personal needs of a subject. That is why a special environment is needed for the formation of creativity as a personal property that ensures a versatile systemic effect on the student.

Psychological and pedagogical conditions influencing the formation of the experience of creative thinking can be divided into objective (situational) and subjective (personal). Subjective conditions are persistent features of a person's character that can influence the conditions caused by a specific situation. Objective conditions include such an organization of educational process when the student's initiative is not suppressed, confidence in their forces and opportunities is formed, independence is stimulated, and an idea is developed. Subjective (personal) conditions are a set of person's characteristics influencing which (with the help of pedagogical approaches, methods, and means) the experience of creative thinking of future specialists is formed. Objective (situational) conditions provide an opportunity for purposeful pedagogical (formative) action, and also orientate it by the set of goals. This collection includes ${ }^{12}$ :

a) The person and behavior of the teacher. The teacher acts as the main actor in the technological process, organizes it, provides concrete practical interaction with students, integrates them into a common system of values, enhances motivational support of students, and activates their creative potential. The creative activity of the students increases when the teacher shows his creativity. The teacher has to create conditions and act in order to bring students the necessary, planned changes in consciousness, thinking, behavior, and relationships; his/her function is a real assessment of students' activity since it is the promotion and punishment that forms and establishes a habit; s/he should be a model and an example of a creative person who can and wish to orient students in their activities;

b) Material and technical base. Any professionally meaningful qualities, any skills, and abilities are based on knowledge. Acquiring the necessary knowledge by students is one of the most important tasks of the educational process. To acquire a sufficient amount of knowledge, students should not only have an interest in academic work and skills in independent teaching and research activities but also have the respective opportunities. These are a literary fund, computer support, the ability to use

\footnotetext{
${ }^{12}$ Иванова И.П. Развитие творческого мышления студентов в условиях проблемно деятельностного обучения / И.П. Иванова. - Ставрополь, 2002.
} 
the information databases of the Internet, and access to the cultural values of society;

c) Organization of the educational process. The organization of the educational process aimed at forming the experience of professional and creative thinking should be characterized by a problem. The necessity for additional information has created the necessity to resolve the contradiction between the existence of the problem and the impossibility of its solution under certain specific conditions. Therefore, this affects the student's motivational sphere-forming cognitive needs.

The process of forming students' creative thinking experience consists of purposeful interaction, co-creation of the teacher and the student in adequate specially organized conditions using the necessary mechanisms, forms, and methods of organizing classes.

\section{CONCLUSIONS}

Creativity is a universal talent common to humanity. Each person is somewhat creative. Consequently, the development of creative abilities can be carried out both at the personal level and the national level. Nowadays, a state program of the development of a creative environment should be formed. This would include all areas from the developing and the educational system including educational psychological and pedagogical activities with youth and families. Thus, the efforts of the state and the public should be aimed at the well-being and welfare of a family, creation of conditions for the development of the individual in society, in the education system, and the family. The family will be able to self-develop and its members can self-fulfill only in this case. All of this determines the necessity of the state family policy in Ukraine which is aimed at strengthening the social institution of the family. The direction of its implementation is social work with the family which takes into account its features as a social system, the primary collective, and a special small social group. Today, at the same time, there is an urgent necessity not only for social support for the family that has some problems in its life but also special work with difficult families which have more serious problems. There is not only a development environment for children in them but human rights violated systematically. Security agencies work traditionally with such families and human rights are protected by law but punishment is not the only way to work with such families. The main thing is to 
preserve the integrity of the family then there must be a long-term social work aimed at re-education of family members. The development state of the family in Ukraine requires a well-balanced state social policy that is aimed at supporting the family.

Consequently, the developed theories and concepts of the development of creative abilities in works of Ukrainian and foreign psychological science need to systematize the development of the factors.

\section{SUMMARY}

The article deals with the issues of development of the creative abilities of a child in modern Ukraine. The modern trends and directions of economic development characterized by natural combination and use of knowledge, information, and creativity are pointed out. The importance of developing creative industries in Ukraine is emphasized. Particular attention is paid to research on the development of creative abilities in educational and family environments. The most significant factors influencing the development of the creative abilities of the individual according to his/her age are analyzed. The basic factors of stimulation of the development of creative abilities based on person-centered character of interaction of the teacher with students, application of psychological and pedagogical technologies that provide the independent activity of students in the process of creative activity, and the systematic nature of educational work with students in conditions of creative and developing environment are determined. It is found that creativity is possible in any organization where innovations and inventions are possible. Creative abilities are developed in conditions that stimulate this process.

\section{REFERENCES}

1. Біла І.М. Психологія дитячої творчості. - К. : Фенікс, 2014. 136 c., C. 61.

2. Бурлачук Л.Ф., Морозов С.М. Словарь-справочник по психодиагностике. - СПб.: 1999. - 528 с.

3. Гиппенрейтер Ю.Б. Общаться с ребенком. Как? / Ю.Б. Гиппенрейтер. - М. : ЧеРо, Сфера, 2003. - 118 с.

4. Дружинин В.Н. Психология : учебник для гуманитарных вузов / В.Н. Дружинин. - [2-е изд.]. - СПб. : Изд. дом ПИТЕР, 2007. $656 \mathrm{c}$. 
5. Иванова И.П. Развитие творческого мышления студентов в условиях проблемнодеятельностного обучения / И.П. Иванова.Ставрополь, 2002.

6. Кривопишина О.А. Психологія творчості [Текст] / О.А. Кривопишина. - Суми: СумДУ, 2009. - 81 с.

7. Леман К. Новий підліток до п’ятниці. / К. Леман. - [2е вид.]. - К. : Брайт Букс , 2017. - 336 с., С. 49.

8. Лучшие психологические тесты для профотбора и профориентации. Описание и руководство к использованию / Отв. ред. А.Ф. Кудряшов. - Петрозаводск: Петроком, 1992. - 319 с.

9. Матюшкин А.М. Проблемные ситуации в мышлении и обучении. - М., 1982.

10. Методичне забезпечення діяльності психологічної служби. Інформаційно-методичний збірник / В.П. Мушинський, Н.В. Савєльєва, Л.О. Морозова. - Дніпропетровськ, 2006. - 44 с.

11. Моргун В.Ф., Тітов І.Г. Основи психологічної діагностики. Навчальний посібник для студентів вищих навчальних закладів. - К.: Видавничий Дім «Слово», 2009. - 464 с.

12. Панок В.Г., Рудь Г.В. Психологія життєвого шляху особистості: Монографія. - К.: Ніка-Центр, 2006. - 280 с.

13. Психологическая диагностика: Проблемы и исследования / Под ред. К.М. Гуревича. - М.: Педагогика, 1981. - 232 с.

14. Развитие и диагностика способностей / Отв. ред. В.Н. Дружинин, В.Д. Шадриков. - М.: Наука, 1991. - 181 с.

15. Хокинс Д. Креативная экономика. Как превратить идеи в деньги. - М.: Классика - XXI, 2011. - 172 с.

16. Якиманська I. Особистісно орієнтована система навчання// Завуч. - 1999. - № 7. - С. 22.

17. Torrance E. P. Rewarding Creative Behaviour. Experiments in classroom creativity / E. P. Torrance. - Prentice Hall, 1965. - P. 353.

\section{Information about the author: Vynohradova V. Ye.} Dr (PhD), Associate Professor, Head of the Psychology and Pedagogy Department of the V. I. Vernadsky Taurida National University 33, I. Kudry str., Kyiv, Ukraine 